\title{
'Chemlali' olive trees in an irrigated grove: effects of tree age on virgin olive oil quality and mineral nutrient distribution in roots, leaves and fruits
}

\author{
Saida Bedbabis ${ }^{1}$, Béchir Ben Rouina ${ }^{2}$, Maria Lisa Clodoveo $^{3}$ and Giuseppe Ferrara ${ }^{4, \star}$ \\ 1 Laboratory of Environment and Biology of Arid Area, Department of Life Science, Faculty of Sciences, P.O. Box. 802, \\ 3018 Sfax, Tunisia \\ 2 Laboratory of Improvement of Olive and Fruit Trees' Productivity, Olive Tree Institute, P.O. Box. 1087, 3000 Sfax, Tunisia \\ 3 Department of Agricultural and Environmental Science, University of Bari Aldo Moro, Via Amendola 165/A, 70126 Bari, Italy \\ 4 Department of Soil, Plant and Food Sciences, University of Bari ‘Aldo Moro', Via Amendola 165/A, 70126 Bari, Italy
}

Received 12 September 2015 - Accepted 26 April 2016

\begin{abstract}
Introduction. The effects of tree age on the quality of olive oil are not very clear. Data on the mineral element content in different plant organs of cv. Chemlali are also very scarce, and the correlation between tree age and mineral content is still unclear. Materials and methods. A two-year study was conducted on irrigated 'Chemlali' olive trees of two different ages (12 years old vs. 24 years old) in order to verify possible effects on either the nutritional balance in different plant organs (leaves, roots, fruits) or the virgin olive oil (VOO) quality. Results and discussion. The 24-year-old trees showed a higher mineral concentration with respect to 12 -year-old trees in roots and fruits, whereas the opposite was reported for the leaves. Total phenols and induction time values were significantly lower in VOO from 24-year-old trees. Palmitic, palmitoleic, stearic and linoleic acid concentrations were higher in VOO of 24-year-old trees. Conclusion. These results can be useful in order to discriminate the characteristics of VOO obtained from trees of different ages and the mineral content data can be used for the optimization of the fertilization schedules with respect to the olive tree age for more sustainable management of olive groves.
\end{abstract}

Keywords: Tunisia / olive / Olea europaea / mineral nutrients / oil composition / phenolics / sustainable orchard management

Résumé - Oliviers 'Chemlali' en verger irrigué : Effets de l'âge des arbres sur la qualité de l'huile d'olive vierge et sur la répartition des éléments minéraux dans la plante. Introduction. Jusqu'à présent l'étude de l'effet de l'âge de l'olivier sur la qualité de l'huile n'est pas claire. De même le suivi du contenu en éléments minéraux dans les différents organes de l'olivier est rare, ainsi que la corrélation entre l'âge de l'olivier et le contenu en éléments minéraux n'est pas claire. Matériels et méthodes. Afin d'étudier l'effet de l'âge des oliviers sur la composition minérale des différents organes (feuilles; racines et fruits) et sur la qualité de l'huile, des oliviers 'Chemlali' irrigués de différents âges (12 et 24 ans) sont choisis durant deux années d'expérimentation. Résultats et discussions. Les teneurs des racines et de fruits en éléments minéraux sont plus importantes chez les arbres âgés de 24 ans que chez ceux âgés de 12 ans. Alors que les teneurs foliaires en éléments minéraux sont plus importantes chez les oliviers âgés de 12 ans. Les teneurs en phénols totaux sont significativement moins importantes dans l'huile des oliviers âgés de 24 ans, de même pour les valeurs de la stabilité oxydative. L'acide palmitique, palmitoléique, stéarique et linoléique se présentent en forte concentration dans l'huile d'olive des arbres âgés de 24 ans. Conclusion. Ces résultats sont utiles pour distinguer les caractéristiques de l'huile d'olive obtenue à partir d'arbres de différents âges ainsi que le contenu minéral des différents organes des plantes peut être utile pour l'optimisation de période de fertilisation des oliveraies pour une gestion plus durable.

Mots clés : Tunisie / olive / Olea europaea / éléments minéraux / composition de l'huile / phénols totaux / gestion durable des vergers

^ Corresponding author: giuseppe.ferrara@uniba.it 


\section{Introduction}

In Tunisia more than 60 million olive trees are spread over 1.6 million ha [1]. Olive oil represents almost $47 \%$ of the Tunisian agri-food exports and 5.5\% of the total exports of the country. Tunisia exports about $70 \%$ of the national production, an average of $165000 \mathrm{t} \mathrm{year}^{-1}$, and is the $4^{\text {th }}$ largest olive oil-producing country in the world after Spain, Italy and Greece [2]. 'Chemlali' is the main Tunisian cultivar and trees are cultivated on 1.3 million ha in northern and central Tunisia. Around $80 \%$ of Tunisia's oil comes from 'Chemlali' [3].

Data referring to the mineral element content in different plant organs of 'Chemlali' are very scarce, and the correlation between tree age and mineral content is still unclear. Leaf diagnosis is the main option for determining the tree nutritional requirements at a specific physiological stage. Leaf analysis, coupled with data on soil chemical parameters, can give more accurate information on the nutritional status of the olive grove in order to schedule fertilization programs. Leaf analysis can also be useful for a) identifying nutritional disorders, b) detecting low nutrient levels before detrimental deficiencies appear, c) measuring the response to fertilization programs and d) detecting toxicities caused by elements such as chloride $(\mathrm{Cl})$, boron (B) and sodium (Na). The agronomic practices, cultivar, pedoclimatic conditions, grade of ripening, harvest time and processing methods [4] can modify olive fruit characteristics and virgin olive oil (VOO) quality, such as polyphenols and volatile compounds [5,6]. Even taking into account all these aspects, the influence of tree age on both the nutritional status of different olive tree organs and VOO quality has been scarcely investigated. The aims of the present study were to investigate the influence of olive tree age (12 years old vs. 24 years old) on the nutritional balance in different plant organs and VOO quality.

\section{Materials and methods}

\subsection{Plant material and experimental site}

The trial was conducted in two years, 2014 and 2015. The olive grove was located in Sfax $\left(34^{\circ} 43 \mathrm{~N}, 10^{\circ} 41 \mathrm{E}\right)$ in Central-Eastern Tunisia. In this geographical area, the rainfall was $254 \mathrm{~mm}$ in 2014 and $128 \mathrm{~mm}$ in 2015 . Olive trees [Olea europaea (L.) cv. Chemlali] were spaced $24 \times 24 \mathrm{~m}$, trained to vase and rainfed. A randomized block design, with two blocks of 1 ha $\left(17\right.$ trees block $\left.{ }^{-1}\right)$ and each block with olive trees of two different ages, was used. The first block consisted of 12-year-old trees (12y-T), whereas the other consisted of 24-year-old trees $(24 \mathrm{y}-\mathrm{T})$. The canopy volume of the trees was $11.24 \mathrm{~m}^{3}$ and $17.55 \mathrm{~m}^{3}$ for $12 \mathrm{y}-\mathrm{T}$ and $24 \mathrm{y}-\mathrm{T}$, respectively. The two blocks had the same clone of 'Chemlali' and were very close to each other. The cultural practices (pruning, pest control, fertilization, tillage, etc.) used were the same for the two blocks. In particular, trees received an irrigation volume which ranged from 4,200 to $5,000 \mathrm{~m}^{3} \mathrm{ha}^{-1}$ for $12 \mathrm{y}-\mathrm{T}$ and $24 \mathrm{y}-\mathrm{T}$, respectively, in order to keep identical experimental conditions (above $6 \%$ of soil water content) in both blocks. In both years of the trial, trees were fertilized with $30 \mathrm{t}$ of decomposed green compost for an input of $285 \mathrm{~kg} \mathrm{~N}, 45 \mathrm{~kg} \mathrm{P}$ and $185 \mathrm{~kg} \mathrm{~K}$.
Table I. Physical and chemical characteristics of the soil in the experimental olive grove. Data represent mean values of three replicates for each depth $(n=4)$.

\begin{tabular}{lccccc}
\hline \multicolumn{5}{c}{ Depth $(\mathrm{cm})$} \\
\hline Parameter & $0-30$ & $30-50$ & $50-80$ & $80-120$ & $120-180$ \\
\hline Clay (\%) & $5.50^{\mathrm{c}}$ & $5.00^{\mathrm{c}}$ & $6.50^{\mathrm{b}}$ & $7.00^{\mathrm{a}}$ & $7.50^{\mathrm{a}}$ \\
Silt (\%) & $5.00^{\mathrm{b}}$ & $2.00^{\mathrm{d}}$ & $4.50^{\mathrm{c}}$ & $5.50^{\mathrm{b}}$ & $6.00^{\mathrm{a}}$ \\
Sand (\%) & $89.50^{\mathrm{b}}$ & $93.00^{\mathrm{a}}$ & $89.00^{\mathrm{b}}$ & $87.50^{\mathrm{b}}$ & $86.50^{\mathrm{b}}$ \\
$\mathrm{N}(\%)$ & $1.05^{\mathrm{a}}$ & $0.50^{\mathrm{b}}$ & $0.32^{\mathrm{c}}$ & $0.37^{\mathrm{c}}$ & $0.30^{\mathrm{c}}$ \\
$\mathrm{K}(\mathrm{ppm})$ & $480^{\mathrm{b}}$ & $380^{\mathrm{c}}$ & $740^{\mathrm{a}}$ & $460^{\mathrm{b}}$ & $420^{\mathrm{bc}}$ \\
$\mathrm{P}(\mathrm{ppm})$ & $40^{\mathrm{a}}$ & $35^{\mathrm{b}}$ & $40^{\mathrm{a}}$ & $25^{\mathrm{c}}$ & $15^{\mathrm{d}}$ \\
OM $^{\mathrm{x}}(\%)$ & $1.69^{\mathrm{a}}$ & $1.10^{\mathrm{b}}$ & $1.01^{\mathrm{b}}$ & $1.02^{\mathrm{b}}$ & $0.65^{\mathrm{c}}$ \\
\hline
\end{tabular}

For each parameter, lower-case letters indicate significant differences among depths according to the LSD test $(P \leqslant 0.05)$. ${ }^{\mathrm{X}} \mathrm{OM}$ : organic matter.

\subsection{Soil characteristics}

Representative soil samples of the volume explored by the roots were taken at $0-180 \mathrm{~cm}$ depth $(30 \mathrm{~cm}$ each) by using a soil auger. The soil samples (four for each depth) were airdried at room temperature, crushed to pass a $2-\mathrm{mm}$ sieve, and mixed thoroughly for analysis. The texture of the soil was determined using the pipette method according to Ge and Or [7]. The soil $\mathrm{pH}$ was determined with a $\mathrm{pH}$ meter $(420 \mathrm{~A}$, Orient) in water $\left(\mathrm{pH}_{\mathrm{H} 2 \mathrm{O}}\right)$ and in saline solution of $0.01 \mathrm{M} \mathrm{CaCl}_{2}$ $\left(\mathrm{pH}_{\mathrm{CaCl} 2}\right)$. The soil/water ratio of the suspensions was $1: 2.5$ $(\mathrm{w} / \mathrm{v})$. The soil of the experimental site was classified as sandy soil according to the USDA classification and was identical in the two blocks. The sand content was very abundant, up to $93.0 \%$ at $30-50 \mathrm{~cm}$. As a consequence, the silt content was very low, ranging from 2.0 to $6.0 \%$, and the clay content varied only from 5.0 to $7.5 \%$, respectively, at $30-50 \mathrm{~cm}$ and $120-180 \mathrm{~cm}$ (table I). The $\mathrm{pH}$ values ranged from 7.50 to 8.20 , falling within the $7.00-8.50$ range, appropriate for olive tree growth [8]. The soil electrical conductivity (EC) values varied from $0.23 \mathrm{dS} \mathrm{m}^{-1}$ at the surface layer, up to $3.74 \mathrm{dS} \mathrm{m}^{-1}$ at $120-180 \mathrm{~cm}$. The organic matter $(\mathrm{OM})$ values ranged from 0.65 to $1.69 \%$, probably because of the application of $30 \mathrm{t}$ of decomposed green compost.

The soil was rich in $\mathrm{N}$ in the superficial layers (table I) as a consequence of the $\mathrm{OM}$ mineralization. The rate of $\mathrm{K}$ in the soil varied between 380 and $740 \mathrm{mg} \mathrm{kg}^{-1}$. The maximum of $740 \mathrm{mg} \mathrm{kg}^{-1}$ was reached at a depth of $80 \mathrm{~cm}$, probably caused by salt leaching, which causes movement of soil nutrients such as $\mathrm{K}$.

\subsection{Root sampling and mineral analysis}

Fine roots were sampled (eight samples per type of tree) in four periods (winter, spring, summer and fall) of each year, placed in paper bags and stored in a portable cooler for the determination of nutrient concentrations. Successively, the roots were dried in an oven $\left(60^{\circ} \mathrm{C}\right)$ and analyzed according to the methods described by [9]. Mineral element (N, P, K and Ca) analysis was carried out after dry-ashing at $450{ }^{\circ} \mathrm{C}$ in a muffle oven (HEROTEC) and digestion of the ashes with $1 \mathrm{M} \mathrm{HNO}_{3}$. 
Total nitrogen was determined with the Kjeldahl method. K was determined by atomic emission spectrophotometry (JENWAY PFP7, Milan, Italy). The Ca was analyzed by atomic absorption spectrophotometry (Perkin Elmer A Analyst 300, Perkin Elmer Inc., Willesley, MA, USA). P in roots was determined by a vanadomolybdate colorimetric procedure with a JENWAY 6405 UV/Vis Spectrophotometer (Milan, Italy).

\subsection{Leaf sampling and mineral analysis}

Fully developed leaves were taken from the middle portion of the current year shoots taken from the external and internal canopy in the four cardinal directions $\left(8\right.$ shoots tree $\left.{ }^{-1}\right)$ for each tree. They were collected each month during the trial period, placed in paper bags and stored in a portable cooler. Successively, the leaves were dried in an oven $\left(60^{\circ} \mathrm{C}\right)$ and analyzed according to the methods described by [9] Analyses of N, P, K and $\mathrm{Ca}$ were done by using the same methods used for roots.

\subsection{Fruit sampling and mineral analysis}

Healthy fruits were hand-picked during ripening (summer) and at harvest. Fruits were sampled from all the olive trees $\left(1 \mathrm{~kg}\right.$ tree $\left.^{-1}\right)$ of each block. The pulp and stone were separated, dried at $60^{\circ} \mathrm{C}$ and successively ground. Mineral analyses were carried out following the same methods previously described for roots and leaves.

\subsection{Olive and oil analyses}

In the two years, the average yield of the two types of tree was $70 \mathrm{~kg}$ and $160 \mathrm{~kg}$ for $12 \mathrm{y}-\mathrm{T}$ and $24 \mathrm{y}-\mathrm{T}$, respectively. Samples of approximately $5 \mathrm{~g}$ of olive pulp from 50 olives were weighed, then dried for $24 \mathrm{~h}$ at $105^{\circ} \mathrm{C}$, cooled for $30 \mathrm{~min}$ in a desiccator and reweighed. The oil content was determined by Soxhlet extraction and was expressed as a percentage of the dry olive paste weight.

Oil extraction was carried out in similar industrial extraction conditions using an Abencor analyzer (MC2 Ingenieria y Sistemas, Sevilla, Spain). Olives $(2.0 \mathrm{~kg})$ were crushed with a hammer mill and were slowly mixed for $30 \mathrm{~min}$ at $25^{\circ} \mathrm{C}$. Then, the paste obtained was centrifuged at 3,500 rpm for $3 \mathrm{~min}$. The oil was separated by decanting, transferred into dark glass bottles and stored in a dark and cool place at $14{ }^{\circ} \mathrm{C}$ (eight samples per type of tree).

Free acidity, expressed as percent of oleic acid (C18:1), was determined by titration of a solution of oil dissolved in ethanol-ether (1:1) with ethanolic potash according to the official methods described in EEC Regulation no. 2568/91 and UV absorption characteristics $\left(\mathrm{K}_{232}\right.$ and $\left.\mathrm{K}_{270}\right)$ were determined according to the European Union Commission [10] and subsequent amendments.

Total phenols were extracted with water: methanol buffer (60:40) three times, from an oil-in-hexane solution, according to the method described by [11] and determined colorimetrically using Folin-Ciocalteu reagent [12]. The absorbance was measured at $727 \mathrm{~nm}$ with a spectrophotometer (Perkin Elmer UV/Vis Spectrophotometer, Norwalk, CT). Results were expressed as $\mathrm{mg}$ caffeic acid $\mathrm{kg}^{-1}$ oil.

The induction time was evaluated by the Rancimat method [13]. Stability was expressed as the oxidation time (hours) with the Rancimat 679 model (Metrohm, Switzerland). Fatty acids were converted to fatty acid methyl esters (FAMEs) according to Cecchi et al. [14]. The FAMEs were prepared by vigorous shaking of an oil solution in hexane $(0.5 \mathrm{~g}$ in $5 \mathrm{~mL})$ with $0.5 \mathrm{~mL}$ of $2 \mathrm{~N}$ methanolic potash and analyzed using a Shimadzu 17 Autosystem gas chromatograph (SP2330, Supelco) equipped with a flame ionization detector (FID) and a fused silica capillary column $(15 \mathrm{~m}$ length $\times 0.25 \mathrm{~mm}$ wide $\times$ $0.15 \mu \mathrm{m}$ film thickness). Nitrogen was used as a carrier gas with a flow through the column of $1 \mathrm{~mL} \mathrm{~min}{ }^{-1}$. The temperatures of the injector and detector were 220 and $250{ }^{\circ} \mathrm{C}$, respectively, while the oven temperature was $180^{\circ} \mathrm{C}$. Results were expressed as a relative percentage of the total area.

\subsection{Statistical analysis}

All data collected were subjected to analysis of variance (ANOVA), with the two treatments as the independent variables. Statistical analyses were carried out with SPSS 10 for Windows (SPSS Inc., Chicago, IL, USA). The mean values of all parameters were compared using the LSD test at $P<0.05$.

\section{Results and discussion}

\subsection{Influence of tree age on seasonal variation of mineral composition of roots}

The age of the olive trees was a key factor in influencing the N, P, K and Ca concentration in roots (table II). Nitrogen is one of the essential nutrients needed by plants and a key mineral for olive trees because it facilitates nutrient uptake by increasing their availability to the plant [15]. The concentration of $\mathrm{N}$ in the roots ranged from 0.85 to $1.65 \%$ (dry weight) and showed the highest values in fall, $1.65 \%(24 \mathrm{y}-\mathrm{T})$ and $1.50 \%$ $(12 \mathrm{y}-\mathrm{T})$. The lowest values were recorded in summer, $0.90 \%$ $(24 \mathrm{y}-\mathrm{T})$ and $0.75 \%(12 \mathrm{y}-\mathrm{T})$.

Phosphorus is an important structural component of olive tree tissues; it is essential for energy storage and transfer (ATP) and its adequate supply at the early growth stage is important for root growth, development of reproductive organs, disease and drought stress resistance [16]. The P concentration in the roots varied between 0.04 and $0.13 \%$, with the highest values in winter, $0.13 \%(24 \mathrm{y}-\mathrm{T})$ and $0.09 \%(12 \mathrm{y}-\mathrm{T})$. The lowest value for the $24 \mathrm{y}-\mathrm{T}$ was recorded in fall $(0.04 \%)$, probably due to high demand for these elements for oil biosynthesis in the olive fruit $[17,18]$. The level of fruit load associated with age directly influenced the annual mineral balance in olive trees. The lowest $\mathrm{P}$ concentration in the roots of $12 \mathrm{y}-\mathrm{T}$ was recorded in spring $(0.04 \%)$, probably due to vegetative growth stimulation.

The potassium content in roots showed the highest values in winter, $0.95 \%(24 \mathrm{y}-\mathrm{T})$ and $0.90 \%(12 \mathrm{y}-\mathrm{T})$. The lowest values were recorded in fall $(0.30 \%)$ for the $24 \mathrm{y}$ - $\mathrm{T}$ and in summer 
Table II. Root and leaf contents of N, P, K and Ca in 24-year-old (24y-T) and 12-year-old (12y-T) olive trees (in 2014 and 2015 ). Data represent mean values of three replicates for each type of tree, year and season $(n=8)$.

\begin{tabular}{|c|c|c|c|c|c|c|c|c|c|c|}
\hline \multirow{2}{*}{ Organ } & \multirow{2}{*}{ Year } & \multirow{2}{*}{ Season } & \multicolumn{4}{|c|}{$24 \mathrm{y}-\mathrm{T}$} & \multicolumn{3}{|c|}{$12 \mathrm{y}-\mathrm{T}$} & \multirow[b]{2}{*}{$\mathrm{Ca}(\%)$} \\
\hline & & & $\mathrm{N}(\%)$ & $\mathrm{P}(\%)$ & $\mathrm{K}(\%)$ & $\mathrm{Ca}(\%)$ & $\mathrm{N}(\%)$ & $\mathrm{P}(\%)$ & $\mathrm{K}(\%)$ & \\
\hline \multirow{8}{*}{ Roots } & \multirow{4}{*}{2014} & Winter & $1.26^{\mathrm{aC}}$ & $0.13^{\mathrm{aA}}$ & $0.90^{\mathrm{aA}}$ & $1.70^{\mathrm{aD}}$ & $1.00^{\mathrm{bC}}$ & $0.09^{\mathrm{bA}}$ & $0.80^{\mathrm{bA}}$ & $1.23^{\mathrm{bD}}$ \\
\hline & & Spring & $1.54^{\mathrm{aB}}$ & $0.07^{\mathrm{aB}}$ & $0.50^{\mathrm{aB}}$ & $3.10^{\mathrm{aB}}$ & $1.39^{\mathrm{bB}}$ & $0.06^{\mathrm{aB}}$ & $0.40^{\mathrm{bB}}$ & $2.30^{\mathrm{bB}}$ \\
\hline & & Summer & $0.90^{\mathrm{aD}}$ & $0.06^{\mathrm{bB}}$ & $0.38^{\mathrm{aC}}$ & $3.30^{\mathrm{aA}}$ & $0.85^{\mathrm{bD}}$ & $0.08^{\mathrm{aA}}$ & $0.19^{\mathrm{bC}}$ & $2.51^{\mathrm{bA}}$ \\
\hline & & Fall & $1.65^{\mathrm{aA}}$ & $0.05^{\mathrm{bB}}$ & $0.30^{\mathrm{aD}}$ & $2.40^{\mathrm{aC}}$ & $1.50^{\mathrm{bA}}$ & $0.08^{\mathrm{aA}}$ & $0.22^{\mathrm{bC}}$ & $1.50^{\mathrm{bC}}$ \\
\hline & \multirow{4}{*}{2015} & Winter & $1.28^{\mathrm{aC}}$ & $0.11^{\mathrm{aA}}$ & $0.95^{\mathrm{aA}}$ & $1.90^{\mathrm{aC}}$ & $1.10^{\mathrm{bC}}$ & $0.07^{\mathrm{bA}}$ & $0.90^{\mathrm{aA}}$ & $1.30^{\mathrm{bB}}$ \\
\hline & & Spring & $1.60^{\mathrm{aA}}$ & $0.06^{\mathrm{aB}}$ & $0.47^{\mathrm{aB}}$ & $2.89^{\mathrm{aA}}$ & $1.25^{\mathrm{bB}}$ & $0.04^{\mathrm{bB}}$ & $0.42^{\mathrm{aB}}$ & $2.40^{\mathrm{bA}}$ \\
\hline & & Summer & $0.91^{\mathrm{aD}}$ & $0.07^{\mathrm{aB}}$ & $0.40^{\mathrm{aBC}}$ & $2.84^{\mathrm{aA}}$ & $0.75^{\mathrm{bD}}$ & $0.07^{\mathrm{aA}}$ & $0.23^{\mathrm{bC}}$ & $2.48^{\mathrm{bA}}$ \\
\hline & & Fall & $1.45^{\mathrm{aB}}$ & $0.04^{\mathrm{bC}}$ & $0.35^{\mathrm{aC}}$ & $2.58^{\mathrm{aB}}$ & $1.40^{\mathrm{aA}}$ & $0.07^{\mathrm{aA}}$ & $0.20^{\mathrm{bC}}$ & $1.49^{\mathrm{bB}}$ \\
\hline \multirow{8}{*}{ Leaves } & \multirow{4}{*}{2014} & Winter & $1.37^{\mathrm{bB}}$ & $0.10^{\mathrm{bA}}$ & $0.71^{\mathrm{bB}}$ & $1.92^{\mathrm{bB}}$ & $2.36^{\mathrm{aB}}$ & $0.13^{\mathrm{aA}}$ & $1.01^{\mathrm{aA}}$ & $2.38^{\mathrm{aA}}$ \\
\hline & & Spring & $1.34^{\mathrm{bB}}$ & $0.08^{\mathrm{bB}}$ & $0.61^{\mathrm{bC}}$ & $1.28^{\mathrm{bC}}$ & $2.30^{\mathrm{aB}}$ & $0.10^{\mathrm{aB}}$ & $0.80^{\mathrm{aB}}$ & $2.28^{\mathrm{aB}}$ \\
\hline & & Summer & $1.28^{\mathrm{bC}}$ & $0.04^{\mathrm{bC}}$ & $0.43^{\mathrm{bD}}$ & $1.24^{\mathrm{bC}}$ & $1.97^{\mathrm{aC}}$ & $0.07^{\mathrm{aC}}$ & $0.63^{\mathrm{aC}}$ & $2.05^{\mathrm{aC}}$ \\
\hline & & Fall & $1.68^{\mathrm{bA}}$ & $0.08^{\mathrm{bB}}$ & $0.91^{\mathrm{bA}}$ & $2.20^{\mathrm{bA}}$ & $2.51^{\mathrm{aA}}$ & $0.10^{\mathrm{aB}}$ & $1.05^{\mathrm{aA}}$ & $2.37^{\mathrm{aA}}$ \\
\hline & \multirow{4}{*}{2015} & Winter & $1.40^{\mathrm{bB}}$ & $0.09^{\mathrm{bA}}$ & $0.70^{\mathrm{bB}}$ & $1.80^{\mathrm{bB}}$ & $2.32^{\mathrm{aB}}$ & $0.11^{\mathrm{aA}}$ & $0.97^{\mathrm{aB}}$ & $2.30^{\mathrm{aB}}$ \\
\hline & & Spring & $1.33^{\mathrm{bBC}}$ & $0.10^{\mathrm{aA}}$ & $0.62^{\mathrm{bBC}}$ & $1.32^{\mathrm{bC}}$ & $2.28^{\mathrm{aB}}$ & $0.09^{\mathrm{aB}}$ & $0.85^{\mathrm{aC}}$ & $2.29^{\mathrm{aB}}$ \\
\hline & & Summer & $1.23^{\mathrm{bC}}$ & $0.06^{\mathrm{bB}}$ & $0.47^{\mathrm{bC}}$ & $1.19^{\mathrm{bC}}$ & $1.90^{\mathrm{aC}}$ & $0.08^{\mathrm{aB}}$ & $0.60^{\mathrm{aD}}$ & $2.08^{\mathrm{aC}}$ \\
\hline & & Fall & $1.78^{\mathrm{bA}}$ & $0.09^{\mathrm{aA}}$ & $0.95^{\mathrm{bA}}$ & $2.27^{\mathrm{bA}}$ & $2.40^{\mathrm{aA}}$ & $0.09^{\mathrm{aB}}$ & $1.10^{\mathrm{aA}}$ & $2.42^{\mathrm{aA}}$ \\
\hline
\end{tabular}

For each element, lower-case and capital letters indicate, respectively, significant differences between the two types of tree within each season (lower-case letter) and among seasons for each type of tree (capital letter) according to the LSD test $(P \leqslant 0.05)$.

$(0.19 \%)$ for the $12 \mathrm{y}-\mathrm{T}$, when there is potassium translocation toward the developing fruit.

Calcium is vital to olive tree growth because it is an essential constituent of cell walls and contributes to the mechanical resistance of tissues; it also acts as an activator of some enzymes. The $\mathrm{Ca}$ concentration in roots ranged from 1.23 to $3.30 \%$. The calcium content in summer was very high, $3.30 \%$ $(24 \mathrm{y}-\mathrm{T})$ and $2.51 \%(12 \mathrm{y}-\mathrm{T})$. The lowest values were recorded in winter, $1.70 \%$ and $1.23 \%$ for $24 \mathrm{y}-\mathrm{T}$ and $12 \mathrm{y}$-T, respectively. The $\mathrm{Ca}$ accumulation in roots may be a strategy of the olive tree in order to reduce absorption of $\mathrm{Na}$; in fact, $\mathrm{Ca}$ plays a key role in limiting the toxic effects of $\mathrm{Na}$ on the integrity of the plasma membrane in root cells [19]. A low concentration of both $\mathrm{Na}$ and $\mathrm{Cl}$ was measured in the roots (data not shown). This result can also explain the salt tolerance of 'Chemlali' through a system based on an exclusion mechanism in the root system to limit the ion (mainly $\mathrm{Na}$ and $\mathrm{Cl}$ ) uptake and translocation from the roots to the shoots. The $\mathrm{Ca}$ accumulation can also explain the decrease of $\mathrm{K}$ in the roots. In fact, $\mathrm{Ca}$ can enhance the selectivity for the uptake and transport of $\mathrm{K}$ toward the other plant organs (leaves, stems, fruits).

In general, higher $\mathrm{N}, \mathrm{P}, \mathrm{K}$ and $\mathrm{Ca}$ concentrations were measured in roots of $24 \mathrm{y}-\mathrm{T}$ compared with $12 \mathrm{y}-\mathrm{T}$. Such differences can probably be ascribed to: (i) a slight absorption of macro-elements by the less wide and developed root system of $12 \mathrm{y}$-T compared with the higher absorption capacity of the bigger root system of $24 \mathrm{y}-\mathrm{T}$ and (ii) the transport of these elements toward the leaves for the shoot growth and tree development, which can happen at higher rates in younger trees.

\subsection{Influence of the tree age on seasonal variation of mineral composition of leaves}

The age of the olive tree is a factor clearly influencing the $\mathrm{N}, \mathrm{P}, \mathrm{K}$ and $\mathrm{Ca}$ concentration in leaves (table II). The concentration of $\mathrm{N}$ in the leaves ranged from 1.23 to $2.51 \%$ and the highest values were measured in fall, $1.78 \%$ and $2.51 \%$ for $24 \mathrm{y}-\mathrm{T}$ and $12 \mathrm{y}-\mathrm{T}$, respectively (table II). The lowest values were recorded in summer, $1.23 \%(24 \mathrm{y}-\mathrm{T})$ and $1.90 \%(12 \mathrm{y}-\mathrm{T})$.

The concentration of $\mathrm{P}$ in the leaves ranged from 0.04 to $0.13 \%$, with the highest values in winter, $0.10 \%$ and $0.13 \%$ for $24 \mathrm{y}-\mathrm{T}$ and $12 \mathrm{y}-\mathrm{T}$, respectively. The lowest values were recorded in summer, $0.04 \%$ and $0.06 \%$, respectively.

The concentration of $\mathrm{K}$ in the leaves varied from 0.43 to $1.10 \%$, with peaks in fall, $0.97 \%(24 \mathrm{y}-\mathrm{T})$ and $1.10 \%(12 \mathrm{y}-\mathrm{T})$. The lowest values were recorded in summer, $0.43 \%(24 \mathrm{y}-\mathrm{T})$ and $0.60 \%(12 \mathrm{y}-\mathrm{T})$. The low $\mathrm{K}$ values were probably a consequence of the low concentration of this element in the decomposed green compost and probably an application of exhausted olive pomace (a by-product of the oil industry) would have increased the $\mathrm{K}$ concentration [20].

The concentration of $\mathrm{Ca}$ in the leaves ranged from 1.19 to $2.42 \%$, and the lowest values were reported in summer, $1.19 \%$ and $2.05 \%$ for $24 \mathrm{y}-\mathrm{T}$ and $12 \mathrm{y}-\mathrm{T}$, respectively.

The mean concentrations of $\mathrm{N}$ and $\mathrm{Ca}$ contents were higher in our samples with respect to the values reported by other authors in Leccino, Barnea and Frantoio cultivars [21-23], probably because of genetic and pedoclimatic differences. The leaf $P$ contents were generally lower than the optimal values for the olive tree, $0.15-0.21 \%$, as reported by $[24,25]$. However, leaf P concentrations were similar to the results reported 
Table III. Mineral composition of fruits harvested from 24-year-old (24y-T) and 12-year-old (12y-T) olive trees (in 2014 and 2015$)$. Data represent mean values of three replicates for each type of tree, year and month $(n=8)$.

\begin{tabular}{|c|c|c|c|c|c|c|c|c|c|}
\hline \multirow{2}{*}{ Year } & \multirow{2}{*}{ Month } & \multicolumn{4}{|c|}{$24 \mathrm{y}-\mathrm{T}$} & \multicolumn{3}{|c|}{$12 \mathrm{y}-\mathrm{T}$} & \multirow[b]{2}{*}{$\mathrm{Ca}(\%)$} \\
\hline & & $\mathrm{N}(\%)$ & $\mathrm{P}(\%)$ & $\mathrm{K}(\%)$ & $\mathrm{Ca}(\%)$ & $\mathrm{N}(\%)$ & $\mathrm{P}(\%)$ & $\mathrm{K}(\%)$ & \\
\hline \multirow{6}{*}{2014} & June & $0.58^{\mathrm{aDE}}$ & $0.20^{\mathrm{aA}}$ & $1.90^{\mathrm{aA}}$ & $3.00^{\mathrm{aB}}$ & $0.56^{\mathrm{aC}}$ & $0.07^{\mathrm{bD}}$ & $1.50^{\mathrm{bA}}$ & $2.70^{\mathrm{bB}}$ \\
\hline & July & $0.62^{\mathrm{aC}}$ & $0.19^{\mathrm{aA}}$ & $1.70^{\mathrm{aC}}$ & $3.20^{\mathrm{aA}}$ & $0.57^{\mathrm{bC}}$ & $0.17^{\mathrm{aB}}$ & $1.52^{\mathrm{bA}}$ & $2.80^{\mathrm{bA}}$ \\
\hline & August & $0.84^{\mathrm{aA}}$ & $0.20^{\mathrm{aA}}$ & $1.80^{\mathrm{aB}}$ & $2.90^{\mathrm{aB}}$ & $0.81^{\mathrm{aA}}$ & $0.19^{\mathrm{aA}}$ & $1.50^{\mathrm{bA}}$ & $2.50^{\mathrm{bC}}$ \\
\hline & September & $0.70^{\mathrm{aB}}$ & $0.16^{\mathrm{aB}}$ & $1.00^{\mathrm{aF}}$ & $1.60^{\mathrm{aD}}$ & $0.60^{\mathrm{bB}}$ & $0.11^{\mathrm{bC}}$ & $1.00^{\mathrm{aD}}$ & $1.40^{\mathrm{bE}}$ \\
\hline & October & $0.55^{\mathrm{aE}}$ & $0.12^{\mathrm{aC}}$ & $1.40^{\mathrm{aE}}$ & $1.70^{\mathrm{aCD}}$ & $0.50^{\mathrm{bD}}$ & $0.10^{\mathrm{bC}}$ & $1.30^{\mathrm{bC}}$ & $1.60^{\mathrm{bD}}$ \\
\hline & November & $0.55^{\mathrm{aE}}$ & $0.12^{\mathrm{aC}}$ & $1.60^{\mathrm{aD}}$ & $1.80^{\mathrm{aC}}$ & $0.48^{\mathrm{bD}}$ & $0.10^{\mathrm{bC}}$ & $1.40^{\mathrm{bB}}$ & $1.60^{\mathrm{bD}}$ \\
\hline \multirow{6}{*}{2015} & June & $0.55^{\mathrm{aC}}$ & $0.21^{\mathrm{aA}}$ & $1.87^{\mathrm{aA}}$ & $2.90^{\mathrm{aA}}$ & $0.55^{\mathrm{aBC}}$ & $0.08^{\mathrm{bB}}$ & $1.55^{\mathrm{bA}}$ & $2.80^{\mathrm{bA}}$ \\
\hline & July & $0.65^{\mathrm{aB}}$ & $0.16^{\mathrm{aB}}$ & $1.79^{\mathrm{aB}}$ & $3.00^{\mathrm{aA}}$ & $0.55^{\mathrm{bBC}}$ & $0.11^{\mathrm{bB}}$ & $1.55^{\mathrm{bA}}$ & $2.90^{\mathrm{bA}}$ \\
\hline & August & $0.80^{\mathrm{aA}}$ & $0.16^{\mathrm{aB}}$ & $1.82^{\mathrm{aB}}$ & $1.56^{\mathrm{bC}}$ & $0.78^{\mathrm{aA}}$ & $0.17^{\mathrm{aA}}$ & $1.52^{\mathrm{bA}}$ & $2.50^{\mathrm{aB}}$ \\
\hline & September & $0.68^{\mathrm{aB}}$ & $0.13^{\mathrm{aC}}$ & $0.90^{\mathrm{bE}}$ & $1.72^{\mathrm{aB}}$ & $0.58^{\mathrm{bB}}$ & $0.10^{\mathrm{bB}}$ & $1.20^{\mathrm{aD}}$ & $1.42^{\mathrm{bD}}$ \\
\hline & October & $0.49^{\mathrm{aD}}$ & $0.11^{\mathrm{abCD}}$ & $1.38^{\mathrm{aD}}$ & $1.68^{\mathrm{aB}}$ & $0.50^{\mathrm{aC}}$ & $0.20^{\mathrm{aA}}$ & $1.33^{\mathrm{aC}}$ & $1.54^{\mathrm{bC}}$ \\
\hline & November & $0.50^{\mathrm{aD}}$ & $0.11^{\mathrm{abCD}}$ & $1.64^{\mathrm{aC}}$ & $1.75^{\mathrm{aB}}$ & $0.51^{\mathrm{aC}}$ & $0.20^{\mathrm{aA}}$ & $1.48^{\mathrm{bAB}}$ & $1.56^{\mathrm{bC}}$ \\
\hline
\end{tabular}

For each element, lower-case and capital letters indicate, respectively, significant differences between the two types of tree within each season (lower-case letter) and among seasons for each type of tree (capital letter) according to the LSD test $(P \leqslant 0.05)$.

by [22] in the Barnea cultivar. In general, leaf N, P, K and Ca contents were higher in $12 \mathrm{y}-\mathrm{T}$ than in $24 \mathrm{y}-\mathrm{T}$, probably due to the different fruit loads of the two types of trees ( $70 \mathrm{~kg}$ in $12 \mathrm{y}-\mathrm{T}$ vs. $160 \mathrm{~kg}$ in $24 \mathrm{y}-\mathrm{T}$ ). Since the developing fruit is a strong sink for nutrients and the yield efficiency was $6.23 \mathrm{~kg}$ olives $\mathrm{m}^{-3}$ of canopy in $12 \mathrm{y}-\mathrm{T}$ and $9.12 \mathrm{~kg}$ olives $\mathrm{m}^{-3}$ of canopy in $24 \mathrm{y}-\mathrm{T}$, fruit of $24 \mathrm{y}-\mathrm{T}$ was capable of attracting more nutrients than those of $12 \mathrm{y}-\mathrm{T}$. In fact, a higher macro-element concentration was reported in the fruit of $24 \mathrm{y}-\mathrm{T}$ compared with $12 \mathrm{y}-\mathrm{T}$.

Leaf macro-element accumulation in $12 \mathrm{y}-\mathrm{T}$ revealed that the young vegetative organs become the main reserve for $\mathrm{N}$, $\mathrm{P}$ and $\mathrm{K}$, with significant dynamic seasonal patterns. In fact, these elements can be accumulated or remobilized according to the physiological needs of the tree [22]. The accumulation of leaf macro-elements in both types of trees during the winter period is functional to the constitution of $\mathrm{N}$, $\mathrm{P}, \mathrm{K}$ and $\mathrm{Ca}$ reserves during vegetative rest to be used in spring. In fact, $\mathrm{N}$ concentration in 'Frantoio' ranged from 1.0 to $1.3 \%$ (dry weight), with higher values in mid-October than in mid-June [23].

In spring, a significant decrease in leaf $\mathrm{N}, \mathrm{K}$ and $\mathrm{P}$ content was found in both types of trees. This decrease is probably ascribable mainly to the high demand for these elements for shoot and fruit growth. The nitrogen stored in leaves during the "off-year" is mobilized at the beginning of the spring of the next year ("on-year") to support both the new shoot growth [26] and the high pollen grain production [27].

The leaf macro-element concentration decreased during summer, and our data are in agreement with those recently reported $[22,28]$. This decrease can be due to the high intake of these elements by olive fruits for growth and the successive oil biosynthesis [26, 29]. However, Fernandez-Escobar et al. [30] and Proietti et al. [31] reported that during the "on-year", more than $60 \%$ of the $\mathrm{N}$ leaf amount was accumulated in the fruits at the end of the year, clearly indicating that the fruit is the most powerful sink for this element. Nutritional reserves $(\mathrm{N}, \mathrm{P}, \mathrm{K}$, etc.) in the roots are in dynamic equilibrium with the centers of use. In fall, these elements are accumulated in the roots and in spring they are mobilized toward growing organs (shoots and fruits) and the growing fruit is the strongest sink [31]. During the ripening period, $60 \%$ of the total $\mathrm{K}$ was found in fruits, and then it remained steady until the moment of harvest [32]. A significant increase in macro-element levels was reported during the fall period and this result can be explained by the sampling time, when fruits had already accumulated nutrients and reached the final size. This hypothesis was confirmed by the unchanged macro-element concentrations in the fruit from October to December. As observed by [25], leaf K concentration increased when olives reached the mature size, and for the cultivar Chemlali this happened in October [18].

\subsection{Influence of the tree age on the seasonal variation of mineral composition of olive fruit}

The mineral contents of olive fruit are reported in table III. The N, P and K contents are significantly higher in $24 \mathrm{y}-\mathrm{T}$ than in $12 \mathrm{y}-\mathrm{T}$, probably because of higher yields in $24 \mathrm{y}-\mathrm{T}(160 \mathrm{~kg})$ than in $12 \mathrm{y}-\mathrm{T}$, which let the fruit of the older trees act as a stronger sink.

Nutrient accumulation in summer demonstrates that $\mathrm{N}$ and $\mathrm{K}$ migrate from leaves to fruits for protein and amino-acid synthesis. In fact, $\mathrm{N}$ is essential for the primary metabolites such as amino acids, proteins and nucleotides, as well as for numerous secondary metabolites [22]. Connor and Fereres [33] found a large amount of $\mathrm{K}$ in olives, in accordance with our results, with an increase in $\mathrm{K}$ from fruit growth to ripening. The significant decrease in $\mathrm{N}, \mathrm{K}$ and $\mathrm{P}$ contents in fruits reported in the fall period may be the consequence of: (i) the increased size of the drupe and (ii) the reduction of water content. 
Table IV. Standard quality parameters, total phenols and induction time of oil obtained from 24-year-old (24y-T) and 12-year-old $(12 \mathrm{y}-\mathrm{T})$ olive trees (in 2014 and 2015). Data represent mean values of three replicates for each type of tree $(n=8)$.

\begin{tabular}{lcc}
\hline Parameters & $24 \mathrm{y}-\mathrm{T}$ & $12 \mathrm{y}-\mathrm{T}$ \\
\hline Water content $(\%)$ & 55.52 & 53.48 \\
Oil content (\%) & 51.91 & 50.96 \\
Free acidity (\%) & 0.28 & 0.26 \\
$\mathrm{~K}_{232}$ & 1.81 & 1.87 \\
$\mathrm{~K}_{270}$ & 0.13 & 0.15 \\
Total phenols (mg kg & -1 \\
Induction time $(\mathrm{h})$ & $92^{\mathrm{b}}$ & $110^{\mathrm{a}}$ \\
\hline
\end{tabular}

Lower-case letters indicate significant differences between the two types of tree according to the LSD test $(P \leqslant 0.05)$.

\subsection{Olive fruit and oil characteristics}

The mean values of water content (WC) in olive fruits only ranged from 53.48 to $55.52 \%$ (table IV). These results are in agreement with the results reported by [34] for the same cultivar. The average oil content (OC) of the olives harvested from both types of trees varied between 50.96 and $51.91 \%$ ( $\mathrm{ta}$ ble $I V)$. The average $\mathrm{WC}$ and $\mathrm{OC}$ values were similar in olives harvested from either $24 \mathrm{y}-\mathrm{T}$ or $12 \mathrm{y}-\mathrm{T}$, and this two-year study indicated that the olive tree age did not influence these parameters in 'Chemlali' olives.

Extra-virgin olive oil is a liquid fat that conforms to a series of chemical and sensory parameters (free fatty acidity $\leqslant 0.8 \mathrm{~g}$ oleic acid $100 \mathrm{~g}^{-1}$ oil, peroxide value $\leqslant 20$ meq $\mathrm{O}_{2} \mathrm{~kg}^{-1}$, $\mathrm{K}_{232} \leqslant 2.50, \mathrm{~K}_{270} \leqslant 0.22$ ) [35], and is free of defects (median of defects $=0$, median of fruity $>0$ ). Both oils from 24y-T and $12 \mathrm{y}$-T belong to the extra-virgin olive oil commercial class ( $t a-$ ble IV). In fact, both oils showed very low percentages of free acidity and peroxide value (index of primary oxidation), and all values were always below the legal limit. The free acidity (FA) of the examined oils ranged from 0.26 to $0.28 \%$ oleic acid. The mean values of the specific extinction coefficients ranged from 1.81 to 1.87 and from 0.13 to 0.15 for $\mathrm{K}_{232}$ and $\mathrm{K}_{270}$, respectively. These results show that the olive tree age did not influence these analytical parameters. The total phenols (TP) contents of oils ranged from 91 to $110 \mathrm{mg} \mathrm{kg}^{-1}$ (as caffeic acid) and were significantly similar to the mean values reported by several authors for 'Chemlali' irrigated trees $[3,36]$.

The only difference was observed for TP, which were significantly lower in oils from $24 \mathrm{y}-\mathrm{T}$ than from $12 \mathrm{y}-\mathrm{T}$ (table IV). This might be ascribed to: (i) the tree age, which can influence the L-phenylalanine ammonia-lyase activity, a key enzyme in the polyphenol biosynthesis [37]; (ii) the K concentration of the fruit, which has been reported to determine an earlier change of fruit color from green to black [38], resulting in a decrease in TP, and (iii) different development of the root system of the two types of trees, less developed in the $12 \mathrm{y}-\mathrm{T}$ (more sensitive to water stress). With regard to this last aspect, in 2015 the lower rainfall $(128 \mathrm{~mm})$ with respect to 2014 $(254 \mathrm{~mm})$ may have stressed the smaller root system of $12 \mathrm{y}-\mathrm{T}$
Table V. Fatty acid (\% d.w.) composition of oil obtained from 24-year-old (24y-T) and 12-year-old (12y-T) olive trees (in 2014 and 2015). Data represent mean values of three replicates for each type of tree $(n=8)$.

\begin{tabular}{lcc}
\hline Parameter & $24 \mathrm{y}-\mathrm{T}$ & $12 \mathrm{y}-\mathrm{T}$ \\
\hline Palmitic acid (C16:0) & $19.05^{\mathrm{a}}$ & $16.48^{\mathrm{b}}$ \\
Palmitoleic acid (C16:1) & $2.59^{\mathrm{a}}$ & $1.96^{\mathrm{b}}$ \\
Stearic acid (C18:0) & 1.87 & 1.80 \\
Oleic acid (C18:1) & 57.59 & 59.23 \\
Linoleic acid (C18:2) & 17.85 & 17.22 \\
Linolenic acid (C18:3) & $0.76^{\mathrm{a}}$ & $0.58^{\mathrm{b}}$ \\
Arachidic acid (C20:0) & 0.37 & 0.36 \\
$\sum$ SFA $^{\mathrm{x}}$ & $21.29^{\mathrm{a}}$ & $18.64^{\mathrm{b}}$ \\
$\sum$ PUFA $^{\mathrm{y}}$ & 18.61 & 17.80 \\
$\sum$ MUFA $^{\mathrm{z}}$ & 60.18 & 61.19 \\
Oleic/linoleic ratio & 3.23 & 3.44 \\
PUFA/MUFA ratio & 0.31 & 0.29 \\
\hline
\end{tabular}

Lower-case letters indicate significant differences between the two types of tree according to the LSD test $(P \leqslant 0.05)$. ${ }^{\mathrm{X}}$ SFA: saturated fatty acids, ${ }^{\mathrm{Y}}$ PUFA: polyunsaturated fatty acids, ${ }^{\mathrm{Z}}$ MUFA: monounsaturated fatty acids.

more with respect to that of $24 \mathrm{y}-\mathrm{T}$, thus increasing the TP content.

Furthermore, the lowest TP content of oil obtained from olives picked from $24 \mathrm{y}-\mathrm{T}$ could also be due to the high $\mathrm{N}$ content of the fruits, which promoted the synthesis of proteins rather than phenols. The mean values of the induction time (IT) ranged from $52(24 \mathrm{y}-\mathrm{T})$ to $65 \mathrm{~h}(12 \mathrm{y}-\mathrm{T})$. The difference was positively correlated $\left(\mathrm{r}^{2}=0.86\right)$ with the total phenol content, as also previously reported [39-42].

The concentrations of fatty acid methyl esters (FAMEs) were within the legal limits (table $V$ ). As expected, the most abundant fatty acid was oleic acid (C18:1). Its contents ranged from 57.59 to $59.23 \%$. Moreover, the amounts of palmitic (C16:0) and palmitoleic (C16:1) acids varied from 16.48 to $19.05 \%$ and from 1.96 to $2.59 \%$, respectively. With regard to the polyunsaturated fatty acids (PUFAs), linoleic acid (C18:2) content ranged from 17.22 to $17.85 \%$, whereas the linolenic acid (C18:3) level varied between 0.58 and $0.76 \%$. The results showed that palmitic, palmitoleic, stearic and linolenic acid concentrations were higher in oils from $24 \mathrm{y}-\mathrm{T}$ than in oils from $12 y-T$. The increase in linoleic and stearic acid contents is probably due to the transformation of oleic acid into linoleic and stearic acids by the oleate and stearoyl-ACP_9 desaturase activity, respectively, enzymes which are active during triacylglycerol biosynthesis [43].

\section{Conclusion}

This study demonstrated that the olive tree age affected the annual macro-element balance in roots, leaves and fruits of olive trees and influenced the virgin olive oil (VOO) quality in an irrigated 'Chemlali' olive grove. The fruit contents of N, P and $\mathrm{K}$ were significantly higher in $24 \mathrm{y}$ - $\mathrm{T}$ than $12 \mathrm{y}$-T, probably 
because the former acted as a stronger sink (higher fruit load) for nutrients from leaves and roots. Moreover, the more developed root system of $24 \mathrm{y}-\mathrm{T}$ could have played a significant role. Finally, the olive tree age affected the total phenol content, induction time and fatty acid composition of the VOO, whereas no significant effects were found on water and oil contents or on standard quality parameters.

\section{References}

[1] Hannachi H., Msallem M., Ben Elhadj S., El Gazzah M., Influence du site biologique sur les potentialités agronomiques et technologiques de l'olivier (Olea europaea L.) en Tunisie, C.R. Biologies 330 (2007) 135-142.

[2] FAOSTAT. Food and Agriculture Organisation of the United Nations. (http://faostat3.fao.org).

[3] Baccouri B., Ben Temime S., Taamalli W., Daoud D., Msallem M., Zarrouk M., Analytical characteristics of virgin olive oils from two new varieties obtained by controlled processing on Meski variety, Food Chem. 14 (2007) 19-34.

[4] Aparicio R., Luna G., Characterisation of monovarietal virgin olive oils, Eur. J. Lipid Sci. Technol. 104 (2002) 614-627.

[5] Kalua C.M., Allen M.S., Bedgood Jr D.R., Bishop A.G., Prenzler P.D., Robards K., Olive oil volatile compounds, flavour development and quality: A critical review, Food Chem. 100 (2007) 273-286.

[6] Nasini L., Gigliotti G., Balduccini M.A., Federici E., Cenci G., Proietti P., Effect of solid olive-mill waste amendment on soil fertility and olive (Olea europaea L.) tree activity, Agric. Ecosyst. Environ. 164 (2013) 292-297.

[7] Gee G.W., Or D., Particle-size analysis, in: Dane, J.H., Topp, G.C. (Eds.), Methods of Soil analysis: Part 4, Physical Methods, SSSA, Madison, WI, 2002.

[8] Bedbabis S., Ben Rouina B., Boukhris M., Ferrara G., Effect of irrigation with treated wastewater on soil chemical properties and infiltration rate, J. Environ. Manage. 133 (2014) 45-50.

[9] Pauwels J.M., Van Ranst E., Verloo M.G., Mvondo Z.A., Manuel de laboratoire de pédologie, Publications Agric. 28 (1992) 191-208.

[10] European Union Commission, Regulation EC 2568/91 on the characteristics of olive oil and olive pomace and their analytical methods, Off. J. Eur. Comm. L 248 (1991) 6-36.

[11] Vazquez Roncero A., Janer del Valle C., Janer del Valle M.L, Determination de polifenoles totales del aceite de oliva, Grasas Aceites 24 (1973) 350-357.

[12] Singleton V.L., Rossi J.A., Colorimetry of total phenolics with phosphomolybdic-phosphotungstic acid reagents, Am. J. Enol. Viticult. 16 (1965) 144-158.

[13] Laubli M.W., Brutel P.A., Determination of the oxidative stability of fats and oils by the Rancimat method, J. Am. Oil Chem. Soc. 63 (1986) 792-795.

[14] Cecchi G., Biasini S., Castano J., Méthanolyse rapide des huiles en solvant note de laboratoire, Rev. Française Corps Gr. 4 (1985) 163-164.

[15] Bouranis D.L., Zakynthinos G., Kapetanos C., Chorianopoulou S.N., Kitsaki C., Drossopoulos J.B., Dynamics of nitrogen and phosphorus partition in four olive tree cultivars during bud differentiation, J. Plant Nutr. 24 (2001) 1535-1550.

[16] Mengel K., Kosegarten H., Kirkby E.A., Appel T., Principles of plant nutrition, Springer, 2001.
[17] Chesworth J.M., Stuchbury T., Scaife J.R., Agricultural Biochemistry, Chapman and Hall, New York, 1998.

[18] Bedbabis S., Ferrara G., Ben Rouina B., Boukhris M., Effects of irrigation with treated wastewater on olive tree growth, yield and leaf mineral elements at short term, Sci. Hortic. 126 (2010) 345-350.

[19] Chartzoulakis K., Loupassaki M., Bertaki M., Androulakis I., Effects of $\mathrm{NaCl}$ salinity on growth, ion content and $\mathrm{CO}_{2}$ assimilation rate of six cultivars, Sci. Hortic. 96 (2002) 235-247.

[20] Ferrara G., Mazzeo A., Matarrese A.M.S., Pacifico A., Fracchiolla M., Al Chami Z., Lasorella C., Montemurro P., Mondelli D., Soil management systems: effects on soil properties and weed flora, S. Afr. J. Enol. Vitic. 36 (1) (2015) 11-20.

[21] Segal E., Dag A., Ben-Gal A., Zipori I., Erel R., Suryano S., Yermiyahu U., Olive orchard irrigation with reclaimed wastewater, agronomic and environmental considerations, Agr. Ecosyst. Environ. 140 (2011) 454-461.

[22] Bustan A., Avni A., Yermiyahu U., Ben-Gal A., Riov J., Erel R., Zipori I., Dag A., Interactions between fruit load and macroelement concentrations in fertigated olive (Olea europaea L.) trees under arid saline conditions, Sci. Hortic. 152 (2013) 44-55.

[23] Proietti P., Gas exchange in senescing leaves of Olea europaea L.. Photosynthetica 35 (1998) 579-587.

[24] Ferreira Llamas J., Basis of fertilization in olive cultivation and the olive tree's vegetative cycle and nutritional needs, in: International Course on the Fertilization and Intensive Cultivation of the Olive, UNDP/FAO/Spanish National Institute for Agricultural Research, Cordoba, Spain, 1984

[25] Fernandez E., Moreno R., Garcia-Creus M., Seasonal changes of mineral nutrients in olive leaves during the alternate- bearing cycle, Sci. Hortic. 82 (1999) 25-45.

[26] Fernández-Escobar R., Moreno R., Sánchez-Zamora M.A., Nitrogen dynamics in the olive bearing shoot, Hort. Sci. 39 (2004) 1406-1411.

[27] Mazzeo A., Palasciano M., Gallotta A., Camposeo S., Pacifico A., Ferrara G., Amount and quality of pollen grains in four olive (Olea europaea L.) cultivars as affected by 'on' and 'off' years, Sci. Hortic. 170 (2014) 89-93.

[28] Erel R., Dag A., Ben-Gal A., Yermiyahu U., Schwartz A., The roles of nitrogen, phosphorus and potassium on olive tree productivity, Acta Hortic. 888 (2011) 259-267.

[29] Jordao P.V., Lietao F., The olive's mineral composition and some parameters of quality in fifty olive cultivars grown in Portugal, Acta Hortic. 286 (1990) 461-464.

[30] Fernández-Escobar R., García-Novelo J.M., Restrepo-Díaz H., Mobilization of nitrogen in the olive bearing shoots after foliar application of urea, Sci. Hortic. 127 (2011) 52-454.

[31] Proietti P., Tombesi A., Effects of gibberellic acid, asparagine and glutamine on flower bud induction in olive, J. Hortic. Sci. Biotech. 71 (3) (1996) 383-388.

[32] Lavee S., Biologie et physiologie de l'olivier, in Plaza S., Janes A. (Eds.), Encyclopédie mondiale de l'olivier, Servers Editorials Estudi Balm, Barcelona, Spain, 1997.

[33] Connor D.J., Fereres E., The physiology of adaptation and yield expression in olives, Hort. Rev. 31 (2005) 155-229.

[34] Gharsallaoui M., Ben Amar F., Khabou W., Ayadi M., Valorisation des ressources en eau non conventionnelles au Sud Tunisien par la culture de l'olivier (Olea europaea L.). In: Meeting International : Gestion des Ressources et Application Biotechnologiques en Aridoculture et Culture Sahariennes : Perspectives pour la valorisation des potentialités du Sahara, Djerba, Tunisia, 2006, p. 7. 
[35] Bedbabis S., Clodoveo, M.L., Rouina B.B., Boukhris M., Influence of irrigation with moderate saline water on 'Chemlali' extra virgin olive oil composition and quality, J. Food Quality 33 (2010) 228-247.

[36] Dhifi W., Hamrouni I., Ayachi S., Chahed T., Saidani M., Marzouk B., Biochemical characterization of some Tunisian olive oils, J. Food Lipids 11 (2004) 287-296.

[37] Martinelli F., Basile B., Morelli G., d'Andria R., Tonutti P., Effects of irrigation on fruit ripening behavior and metabolic changes in olive, Sci. Hortic. 144 (2012) 201-207.

[38] Chartzoulakis K.S., Psarras G., Vemmos S., Loupassaki M., Effects of salinity and potassium supplement on photosynthesis, water relations and $\mathrm{Na}, \mathrm{Cl}, \mathrm{K}$ and carbohydrate concentration of two olive cultivars, Agric. Res. 27 (2004) 75-84.

[39] Gomez-Alonso S., Salvador M.D., Fregapane G., Phenolic compounds profile of 'Cornicabra' virgin olive oil, J. Agr. Food Chem. 50 (2002) 6812-6817.
[40] Andrews P., Busch J.L., De Joode T., Groenewegen P., Alexandre H., Sensory properties of virgin olive oil, polyphenols: identification of deacetoxy-ligstroside aglycon as a key contributor to pungency, J. Agr. Food Chem. 51 (2003) 1415-1420.

[41] Amirante P., Clodoveo M.L., Dugo, G., Leone A., Tamborrino A., Advance technology in virgin olive oil production from traditional and de-stoned pastes: Influence of the introduction of a heat exchanger on oil quality, Food Chem. 98 (2006) 797-805.

[42] Caponio F., Summo C., Clodoveo M.L., Pasqualone A., Evaluation of the nutritional quality of the lipid fraction of gluten-free biscuits, Eur. Food Res. Technol. 227 (2008) 135-139.

[43] Sanchez J., Harwood J.L., Biosynthesis of triacylglycerols and volatiles in olives, Eur. J. Lipid Sci. Tech. 104 (2002) 564-573.

Cite this article as: Saida Bedbabis, Béchir Ben Rouina, Maria Lisa Clodoveo, Giuseppe Ferrara. 'Chemlali' olive trees in an irrigated grove: effects of tree age on virgin olive oil quality and mineral nutrient distribution in roots, leaves and fruits. Fruits 71 (2016) 221-228. 